\title{
Biogenesis of Silver Nano Particles by Endophytic Fungi and their Applications in Clinical Medicines
}

\author{
Sardul Singh Sandhu* and Harshita Shukla \\ Department of Biological Sciences, RD University, India
}

Submission: September 08, 2017; Published: September 25, 2017

*Corresponding author: Sardul Singh Sandhu, Department of Biological Sciences, RD University, India, Email: ssandhu@rediffmail.com

\begin{abstract}
In the last decade tremendous applications of nano particles has drawn great scientific interest of researchers leading to high demands for their synthesis. Currently, green synthesis of nano particles using biological agents has emerged as an attractive alternative to physical and chemical methods. Silver has been known for its medicinal properties since time immemorial which increases multiple times on reducing to nano scale size. Hence silver nano particles have taken a centre stage amongst all types of metal nano particles in terms of their therapeutic potential. The present review therefore gives an overview of silver nano particles synthesis using fungi and their varied applications in the field of medicine.
\end{abstract}

Keywords: Endophytic fungi; Silver nano particles; Biosynthesis; Eco friendly

\section{Introduction}

Nano particles with a characteristic dimension in the range of $1-100 \mathrm{~nm}$ are at the leading edge of nano science and nanotechnology. In recent years nano materials, and specifically metal nano particles, have received much attention in different fields of science and technology [1,2]. Physicochemical properties of nano particles are quite different to those of the bulk materials because of their extremely small size and high surface area to volume ratio of [3]. These properties make them applicable to diverse field's viz., drug delivery, biological labeling, catalysis chemical imaging, electronics etc. [1,2]. The size, shape, and crystal structure of metal nano particles greatly influence their optical, electronic, and catalytic properties, for example, silver $\mathrm{Ag})$ and gold $\mathrm{(Au}$ ) nano crystals of different shapes exhibit different optical scattering properties $[1,4]$.

Thus, synthesis of metal nano particles with defined morphology gained much interest and has now become a prolific area of investigation. An array of physical and chemical methods viz., laser ablation [5], ion sputtering [6], solvothermal synthesis [7], chemical reduction [8], and sol-gel [9] methods has been used successfully to synthesize noble metal nano particles. But these methods remain expensive and involve the use of hazardous chemicals [10].

Therefore, there is a growing concern to develop simple, cost-effective, sustainable and eco-friendly methods for nano particle synthesis. Biological synthesis of nano particles has recently emerged as an attractive approach for this purpose. It is a green chemistry approach that interconnects nanotechnology and biotechnology. It involves the use of biological systems for synthesis of nano particles. Both unicellular and multicellular organisms are known to produce metal nano particles either intracellular or extracellular [11]. Biosynthesis of gold, silver, gold-silver alloy, selenium, tellurium, platinum, palladium, silica, titania, zirconia, quantum dots, magnetite and uraninite nano particles by bacteria $[12,13]$, actinomycetes $[14]$, fungi $[15,16]$, yeasts [17], viruses [18], phototrophic eukaryotes such as plants [19], algae [20], diatoms [21] and human cell lines [22] have been reported.

Owing to the rich biodiversity of microorganisms, their potential as biological materials for nano particle synthesis is yet to be fully explored. Fungi are more advantageous as compared to other microorganisms in many ways. Fungal mycelia mesh can withstand flow pressure, agitation and other conditions in bioreactors or other chambers as compared to plant materials and bacteria. These are fastidious to grow and easy to handle. The extracellular secretions of reductive proteins are more and can be easily handled in downstream processing. Since nano particles are precipitated outside the cell, they are devoid of unnecessary cellular components and can be directly used in various applications. 


\section{Why Silver Nano Particles???}

There has been an alarming increase in the number of antibiotic resistant microbes [23]. This has resulted in an inevitable and urgent need for development of novel antimicrobial agents. One of the promising approaches for overcoming antibiotic resistance of microorganisms is the use of silver nano particles. It has been known since ancient times that silver and its compounds are effective antimicrobial agents [2426]. Compared with other metals, silver exhibits higher toxicity to broad spectrum of microorganisms while it exhibits lower toxicity to mammalian cells [27]. Silver ion has been known to be effective against a broad range of microorganisms including antibiotic-resistant strains [28]. Silver nano particles with higher surface to volume ratio compared to common metallic silver have shown better antimicrobial activity. Mostly at low concentrations silver nano particles are also non-toxic to the mammalian cells [29]. Silver nano particles have been known for a long time but have not been given due attention.

\section{Mechanism of Action of Silver Nano Particles}

Silver nano particles can disturb functions of cell membranes such as permeability and respiration. They get attached to the cell membrane and also penetrate inside the bacteria. Inside the bacterial cells silver nano particles can disturb functions of sulphur containing proteins and phosphorus-containing compounds such as DNA by effectively reacting with them leading to the inhibition of enzyme functions [30,31]. The nano particles bind to proteins and DNA and damage them by inhibiting replication. Thus, silver nano particles interrupt the respiratory chain and cell division leading to cell death [32-34]. In addition, complex action mechanisms of silver metal decrease the probability of bacteria developing resistance to them.

\section{Endophytic Fungi as Bio Factories of Silver Nano Particles}

Over the past decades, Endophytic fungi have attracted increasing attention among taxonomists, mycologists, ecologists, chemists, and evolutionary biologists [35]. While a number of reports are available on the biological synthesis of AgNPs, the potential of Endophytic fungi that colonize in living internal tissues of plants without causing any immediate, overt negative effects [36] has not yet been tapped. Very few reports are available where in Endophytic fungi were used for the synthesis of nano particles. In one such study, an Endophytic fungus Colletorichum $s p$. isolated from Pellargonium graveolens grave lens was employed for the extracellular synthesis of gold nano particles [37].

Another study revealed that Aspergillus clavatus (AzS-275), an Endophytic fungus isolated from sterilized stem tissues of Azadirachta indica synthesized AgNPs possessing antibacterial activity [38]. Recently, Endophytic fungi Aspergillus conicus, Penicillium janthinellum and Phomosis sp. were isolated from Avicennia marina, Suaeda monica and Rhizophora mucronatamangrove plant leafs and used for extracellular biosynthesis of silver nano particles [39].

Five endophytic fungi were isolated from the mangrove leaves of Rhizophora annamalayanna and among them $A$. terreus produced silver nano particles extracellularly. In vitro antidermatophytic activity of synthesized silver nano particles was also analyzed against Trichophyton rub rum, Epidermophyton floccosum and Trichophyton mentagrophytes [40]. In the same way antibacterial activity of silver nano particles synthesized extracellularly by an endophytic fungus Pestalotia $s p$ isolated from leaves of Syzygium cumini (L) was reported [41]. The biosynthesized silver nano particles exhibited good antibacterial activity against pathogenic bacteria viz., Staphylococcus aureus (ATCC-25923) and Salmonella typhi (ATCC-51812). These studies therefore suggest that silver nano particles are the ideal candidates for the development of novel antimicrobial products which are said to be antimicrobials of new generations [42].

\section{Applications of Silver Nano Particles in Clinical Medicine}

The applications in the field of clinical medicine have been known since ancient time. Silver and its compounds were used in the treatment of various diseases viz., wounds, wart removal, epilepsy, venereal infections, acnes and ulcer debridement [24]. With advancement in the field of nanotechnology availability of silver nano particles have increased which are more stable than conventionally used silver compounds. Out of all kinds of metallic nano particles silver nano particles have shown most promising results in the field of biomedicine due to their biomedical activities. The activity of silver nano particles is largely controlled by their size, shape and compositions which have attracted the attention of researchers towards synthesizing and characterizing silver nano particles.

The application of nano silver can be broadly divided into diagnostic and therapeutic uses:

\section{Nano silver in diagnosis and imaging}

Effective diagnosis of disease condition play vital role in its early treatment and cure. Recently diagnostic tools with silver nano particles have emerged as powerful analytical tools for diagnosis of various diseases. For example, Surfaceenhanced Raman spectroscopy (SERS), involving the use of metallic nanostructures in the form of silver nano rods has been successfully used in the detection of four strains of respiratory syncytial virus (RSV) [43]. A similar study proposed the promising application of $\mathrm{Au}-\mathrm{Ag}$ nano rods conjugated multiple aptamers, in cancer cell recognition. Besides disease diagnosis these tools could also be used for various cellular [44].

\section{Nano particles in therapeutics}

Silver Nano particles have several medicinal properties which makes them useful in therapeutic industry. Some of its therapeutic applications are as follows: Wound dressing: The 
application of silver nano particles in

a. Wound dressing for fast and effective wound healing is well documented since time immemorial [45]. There are several examples of wound dressings involving the use of silver nano particles, but out of them Acticoat $₫$, is the most commonly used and first commercial dressing consisting of two layers of polyamide ester membranes covered with nano crystalline silver ions. It exhibits strong bactericidal activity against pathogenic bacterial strains [46]. Besides healing, silver nano particles also minimize the secondary bacterial infections around the wounded area.

According to a study performed by Tredget et al. [47] it was found that out of 30 burn patients secondary bacteraemia, were found to be less in patients treated with silver nano particles than those treated with $0.5 \%$ silver nitrate solution. In a similar study Sibbald et al. [48] concluded that the use of silver nano particles dressing on a variety of chronic nonhealing wounds induces a beneficial protecting effect on the wound site from bacterial contamination. Silver nano particles promote wound healing through various biological effects viz., facilitating the proliferation and migration of keratinocyte, differentiation of fibroblasts into my fibroblasts, modulation of various cytokines [49], and development of well vascularized granulation tissue [50]. These findings were supported in other studies [51]. Therefore, silver nano particles have promising applications in wound healing.

b. Anti-bactereial agent Silver compounds are known to possess antibacterial activity since ancient times and were used as disinfectants against both aerobic and anaerobic bacteria. Their mechanism of action includes precipitation of bacterial cellular proteins and blocking of micro bial respiratory chain system $[52,53]$. Before the advent of silver nano particles, silver nitrate was an effective antibacterial agent used clinically [54,55]. Afterwards, the use of silver sulfadiazine (a combination of silver and sulphonamide) in the treatment of burns exists even to this day [56].

Silver returned to prominence recently due to the emergence of antibiotic-resistant bacteria as a result of the overuse of antibiotics [57,42]. Recently, silver nano particles have gained much attention of researchers because of their antibacterial efficiency. The mechanism of antibacterial activity of silver nano particles is not clearly understood yet but has been found to be similar to that of conventional silver compounds. However, because of the larger surface area to volume ratio, AgNPs may have much better efficiency.

c. Anti-inflammatory Agent: Apart from being an excellent anti-bacterial agent, the AgNPs have anti-inflammatory properties. Various studies have suggested the potential anti-inflammatory property of silver nano particles. Silver nano particles greatly reduce the degree of post-operative fibrous adhesions caused due to inflammation and thus play a remedial role in inflammatory conditions. On the other hand, inflammation has been noted to play a significant part in the formation of post-operative adhesions. In an experiment low levels of the pro-inflammatory cytokine IL- 6 were found in animals treated with AgNPs using quantitative real-time RTPCR.

d. On the other hand higher levels of mRNA, an antiinflammatory cytokine, were found in AgNPs treated group in comparison with other silver compounds [58]. Likewise Bhol \& Schechter [59] utilized AgNPs in a rat model of ulcerative colitis and confirmed that silver nano particles improved the healing process by inducing direct anti-inflammatory effect. In both models, although the set of pro-inflammatory cytokines measured were different from (IL-1; TNF-) [59].

\section{Silver Nano particles in Catheters}

a. Central venous catheters: Central venous catheters (CVC) are most commonly used in hospitals particularly in the United States (5million/year). But the use of CVCs is usually accompanied with infective complications, viz., catheter-related bloodstream infection estimated at around 80000 cases annually $[60,61]$. This could be decreased via impregnation of catheters with antibiotics [62-64]. But continuous use of the same could lead to gradual emergence of bacterial resistance. However, the incidence of catheterrelated blood stream infections decreases on the use of new generation silver-impregnated catheters containing an inorganic silver powder, on which silver ions are bonded with an inert ceramic zeolite for clinical use. Studies have also shown that there has been lower colonization by coagulasenegative staphylococci in the silver-impregnated CVC [65]. Therefore these catheters should be brought into more use in future for clinical purpose.

b. Vascular prosthesis: Development of infectionresistant prosthetic grafts has become the greatest interest of researchers in vascular surgery. Recently, the use of the InterGard Silver ${ }^{\circledR}$ bifurcated polyester graft coated with collagen and silver in vascular surgery represents promising application of nano silver in this field [66].

c. Ventricular drainage catheters: These are commonly used for the drainage of external cerebrospinal fluid (CSF). But insertion of temporary external ventricular drainage (EVD) is usually accompanied with complications like bacterial colonization of the catheter, resulting in ventriculomeningitis and encephalitis. These complications are minimized to a great extent by the use of silver-impregnated ventricular catheters [67].

Silver Nano particles in Orthopedic: The conventionally used biomaterials viz., bone cement based on polymethylmetacrylate (PMMA) is prone to bacterial infections when implanted into the human body [68]. Recently, the use of bone cement loaded with nano silver has emerged as an attractive alternative to these biomaterials in orthopedics [69]. Nano silver-loaded bone cement has 
shown high antibacterial activity against all multi drug resistant bacteria. Similarly, ultra high molecular weight polyethylene (UHMWPE) used as a joint replacement component in orthopedics is associated with major problems like concomitant debris generation leading to subsequent inflammation. These problems are considerably reduced by incorporation of silver nano particles leading to both physical and chemical stabilization of the polymer surface layer toward friction oxidation and degradation. Besides this, silver nano particle also increases UHMWPE biocompatibility and antimicrobial activity.

Silver Nano particles in surgical mesh: The use of silver nano particles polypropylene mesh in surgical meshes has eliminated the risk of nocosomial infections caused due to implanted prosthetic materials [70]. In these meshes silver nano particles continue to diffuse off the mesh and exhibit sustained bactericidal activity [71]. These results clearly indicate silver nano particles-coated polypropylene mesh can decrease the prosthetic infection rate and the host inflammatory response in the clinical setting.

\section{Future Therapeutic Applications}

\section{Antiviral drug}

Silver nano particles possess significant antiviral properties which are of great medicinal interest. Recent studies have shown that silver nano particles exhibited anti-HIV-1 activities in Hut/ CCR5 by inhibiting HIV-1 replication [72]. Further, these nano particles did not show acute cytotoxicity to either the Hut/CCR5 cells or to normal peripheral blood mononuclear cells.

\section{Anti-platelet agent}

Thrombotic disorders have emerged as serious problem tin clinical medicine. The conventional treatments for this include anticoagulant and thrombolytic therapy that may lead to serious bleeding complications [73]. Recently the antiplatelet properties of silver nano particles have been demonstrated by Shrivastava et al. [74]. During this study it was found that silver nano particles inhibit integrin-mediated platelet functional responses like aggregation, secretion, adhesion to immobilized fibrinogen or collagen and retraction of fibrin clot, thereby treating thrombotic disorders. The results showed significant inhibition of platelet functions with a relatively low dose of AgNPs [74].

\section{Effects on stem cells}

According to previous reports silver nano particles promote proliferation of the epidermal stem cells in skin stem cells, which play the most important roles for repairing the epidermis, regenerating hair and maintaining tissue homeostasis after injury.

\section{Conclusion}

The advancements in nanotechnology have created new therapeutic horizons. Above review clearly reveals the potential benefits and wide range applications of silver nano particles.
Biosynthesis of silver nano particles provides an attractive alternative for the hazardous chemical and physical methods of nano particles synthesis. Endophytic fungi surely represents great medium for the biosynthesis of silver nano particles. Biosynthesized silver nano particles possess several therapeutic properties viz., antimicrobial, anti-inflammatory, anti cancer, antioxidant etc. Because of their extremely small size silver nano particles are highly target specific and hence could be developed as broad spectrum therapeutic agents. But more research is needed to be done regarding the mechanism of synthesis so that it could be further exploited for the generation of different functional varieties of silver nano particles. Realizing the wide array of applications of silver nano particles more biosystems should be searched for the large scale biosynthesis of eco friendly silver nano particles.

\section{References}

1. Daniel MC, Astruc D (2004) Gold nano particles: assembly, supramolecular chemistry, quantum-size-related properties, and applications toward biology, catalysis, and nanotechnology. Chem Rev 104(1): 293-346.

2. Huang J, Li Q Sun D, Lu Y, Su Y, et al. (2007) Biosynthesis of silver and gold nano particles by novel sundried Cinnamomum camphora leaf. Nanotechnology 18(10).

3. ElSayed MA (2001) Some interesting properties of metals confined in time and nano meter space of different shapes. Accounts of Chemical Research 34(4): 257-264.

4. Roudner E (2006) Size Matters; Why nano materials are different. Chem Soc Rev 35(7): 583-592.

5. Mafune F, Kohno J, Takeda Y, Tamotsu K (2001) Dissociation and aggregation of Gold nano particles under laser irradiation. Journal Physical Chemistry B 105(38): 9050-9056.

6. Raffi M, Hussain F, Bhatti TM, Akhter JI, Hameed A, et al. (2008) Antibacterial characterization of silver nano particles against E: coli ATCC-15224. J Mater Sci Technol 24(2): 192-196.

7. Rosemary MJ, Pradeep T (2003) Solvothermal synthesis of silver nano particles from thiolates. Journal of Colloid and Interface Science 268(1): 81-84.

8. Chaki NK, Sundrik SG, Sonawane HR, Vijayamohanan K (2002) J Chem Soc Chem Commun 76.

9. Shukla S, Seal S (1999) Cluster size effect observed for gold nano particles synthesized by sol-gel technique as studied by X-ray photoelectron spectroscopy. Nano Structured Materials 11(8): 11811193.

10. Sunkar S, Nachiyar CV, Prakash PB (2015) Biological Synthesis of Gold Nano particles using Endophytic Fungi. Der Pharma Chemica 7(2): 3138.

11. Gajbhiye M, Kesharwani J, Ingle A, Gade A, Rai M, et al. (2009) Fungusmediated synthesis of silver nano particles and their activity against pathogenic fungi in combination with fluconazole. Nanomedicine 5(4): 382-386.

12. Beveridge TJ, Murray RGJ (1976) Uptake and retention of metals by cell walls of Bacillus subtilis. Journal of Bacteriology 127(3): 1502-1518.

13. Wen L, Lin Z, Gu P, Zhou J, Yao B, et al. (2009) Extracellular biosynthesis of mono dispersed gold nano particles by a SAM capping route. Journal of Nano particle Research 11(2): 279-288.

14. Ahmad A, Mukherjee P, Senapati S (2003) Extracellular biosynthesis of silver nano particles using the fungus Fusarium oxysporum. Colloids 
and Surfaces B: Biointerfaces 28(4): 313-318.

15. Vigneshwaran N, Kathe AA, Varadarajan PV, Nachane RP, Balasubramanya RH, et al. (2007) Silver-protein (core-shell) nanoparticle production using spent mushroom substrate. Langmuir 23(13): 7113-7117.

16. Shaligram SN, Bule M, Bhambure R, Singhal SR, Singh KS, et al. (2009) Biosynthesis of silver nano particles using aqueous extract from the compactin producing fungal. Process Biochemistry 44(8): 939-943.

17. Gericke M, Pinches A (2006) Biological synthesis of metal nano particles. Hydrometallurgy 83(1-4): 132-140.

18. Shenton W, Douglas T, Young M, Stubbs G, Mann S (1999) Inorganicorganic nano tube composites from template mineralization of Tobacco mosaic virus. Advanced Material 11(3): 253-256.

19. Shankar SS, Rai A, Ahmad A, Sastry M (2004) Rapid synthesis of $\mathrm{Au}, \mathrm{Ag}$ and bimetallic $\mathrm{Au}$ core-Ag shell nano particles using neem (Azadirachta indica) leaf broth. Journal of Colloid and Interface Science 275(2): 496-502.

20. Singaravelu G, Arockiamary SJ, Kumar GV, Govindaraju K (2007) A novel extracellular synthesis of monodisperse gold nano particles using marine alga Sargassum wightii Greville. Colloids Surf B Biointerfaces 57(1): 97-101.

21. Pum D, Sleytr UB (1999) The application of bacterial S-layers in molecular nanotechnology. Trends Biotechnology 17(1): 8-12.

22. Anshup A, Venkataraman JS, Subramanium C, Kumar RR, Priya S, et al. (2005) Growth of Gold Nano particles in Human Cells. Langmuir 21(25): 11562-11567.

23. Goffeau A (2008) Drug resistance: the fight against fungi. Nature 452(7187): 541-542.

24. Klasen HJ (2000) A historical review of the use of silver in the treatment of burns II. Renewed interest for silver. Burns 26(2): 131-138.

25. Silver S (2003) Bacterial silver resistance: molecular biology and uses and misuses of silver compounds. FEMS microbiol Rev 27(2-3): 341353.

26. Cho KH, Park JE, Osaka T, Park SG (2005) The study of antimicrobial activity and preservative effects of nano silver ingredient. Electrochima Acta 51(5): 956-960.

27. Zhao GJ, Stevens SE (1998) Multiple parameters for the comprehensive evaluation of the susceptibility of Escherichia coli to the silver ion. Biometals 11(1): 27-32.

28. Sharma VK, Yngard RA, Lin Y (2009) Silver nano particles: green synthesis and their antimicrobial activities. Advances in Colloid and Interface Science 145(1-2): 83-96.

29. Baker C, Pradhan A, Pakstis L, Pochan DJ, Shah SI, et al. (2005) Synthesis and antibacterial properties of silver nano particles. J Nanosci Nanotechnol 5(2): 244-249.

30. Singh M, Singh S, Prasad S, Gambhir IS (2008) Nanotechnology in Medicine and antibacterial effects of silver nano particles. Digest journal of Nanomatrials and Biomaterials 3(3): 115-122.

31. Gordan O, Slenters TV, Brunetto PS (2010) Antimicrobial Agents Chemotherapy 54: 4208-4218.

32. Feng QL, Wu J, Chen GQ Cui FZ, Kim TM, et al. (2000) A mechanistic study of the antibacterial effect of silver ions on Escherichia coli and Staphylococcus aureus. J Biomed Mater Res 52(4): 662-668.

33. Sondi I, Salopek-Sondi B (2004) Silver nano particles as antimicrobial agent: a case study on E. coli as a model for Gram-negative bacteria. Journal of Colloid Interface Science 275(1): 177-182.

34. Song HY, Ko KK, Oh LH, Lee BT (2006) Fabrication of silver nano particles and their antimicrobial mechanisms. European Cell and Materials journal 11(1): 58.
35. Saikkonen K (2007) Forest structure and fungal endophytes. Fungal Biology Reviews 21(2-3): 67-74.

36. Bacon CW, White JF (2000) Microbial endophytes. Marcel Dekker Inc., New York, USA.

37. Shankar SS, Ahmad A, Sastry M (2003) Geranium leaf assisted biosynthesis of silver nano particles. Biotechnol Prog 19(16): 16271631.

38. Verma VC, Kharwar RN, Gange AC (2010) Biosynthesis of antimicrobial silver nano particles by the endophytic fungus Aspergillus clavatus. Nanomedicine 5(1): 33-40.

39. Bharathidasan R, Panneerselvam A (2012) Biosynthesis and characterization of silver nano particles using endophytic fungi Aspergillus concius, Penicillium janthinellum and Phomosis sp.

40. Rathna GS, Elavarasi A, Peninal S, Subramanian J, Mano G, et al. (2013) Extracellular Biosynthesis of Silver Nanoparticles by Endophytic Fungus Aspergillus terreus and its Anti-dermatophytic Activity. International Journal of Pharmaceutical and Biological Archieves 4(3): 481-487.

41. Raheman F, Deshmukh S, Ingle A, Gade A, Rai M, et al. (2011) Silver nano particles: Novel antimicrobial agent synthesized from an endophytic fungus Pestalotia sp. isolated from leaves of Syzygium cumini. Nano Biomed Eng 3: 174-178.

42. Rai M, Yadav A, Gade A (2009) Silver nano particles as a new generation of antimicrobials. Biotechnol Adv 27(1): 76-83.

43. Shanmukh S, Jones L, Zhao YP, Driskell JD, Tripp RA, et al. (2008) Identification and classification of respiratory syncytial virus (RSV) strains by surface-enhanced Raman spectroscopy and multivariate statistical techniques. Anal Bioanal Chem 390(6): 1551-1555.

44. Huang YF, Chang HT, Tan WH (2008) Cancer cell targeting using multiple aptamers conjugated on nanorods. Analytical Chemistry 80(3): 567-572.

45. Fong J, Wood F (2006) Nano crystalline silver dressings in wound management: a review. Int J Nanomedicine 1(4): 441-449.

46. Wright JB, Lam K, Burrell RE (1998) Wound management in an era of increasing bacterial antibiotic resistance: a role for topical silver treatment. Am J Infect Control 26(6): 572-577.

47. Tredget EE, Shankowsky HA, Groeneveld A, Burnell R (1998) A matched-pair, randomized study evaluating the efficacy and safety of Acticoat silver-coated dressing for the treatment of burn wounds. J Burn Care Rehabil 19(6): 531-537.

48. Sibbald RJ, Contreras-Ruiz J, Coutts P, Fierheller M, Rothman A, et al. (2007) Bacteriology, inflammation, and healing: a study of nanocrystalline silver dressings in chronic venous leg ulcers. Adv Skin Wound Care 20(10): 549-558.

49. Liu X, Lee PY, Ho CM, Lui VC, Chen Y, et al. (2010) Silver nano particles mediate differential responses in keratinocytes and fibroblasts during skin wound healing. ChemMedChem 5(3): 468-475.

50. Wright JB, Lam K, Buret AG, Olson ME, Burell RE, et al. (2002) Early healing events in a porcine model of contaminated wounds: effects of nanocrystalline silver on matrix metalloproteinases, cell apoptosis and healing. Wound Repair Regen 10(3): 141-151.

51. Lansdown AB (2002) Silver toxicity in mammals and how its products aid wound repair. J Wound Care 11(5): 173-177.

52. Thomas V, Yallapu MM, Sreedhar B, Bajpai SK (2007) A versatile strategy to fabricate hydrogel-silver nano composites and investigation of their antimicrobial activity. J Colloid Interface Sci 315(1): 389-395.

53. Gravante G, Caruso R, Sorge R, Nicoli F, Gentile P, et al. (2009) Nanocrystalline silver: a systematic review of randomized trials conducted on burned patients and an evidence based assessment 
of potential advantages over old silver formulations. Ann Plast Surg 63(2): 201-205

54. Monteiro DR, Gorup LF, Takamiya AS (2009) The growing importance of materials that prevent microbial adhesion: antimicrobial effect of medical devices containing silver. Int J Antimicrob Agents 34(2): 103110.

55. Chen X, Schluesener HJ (2008) Nanosilver: A nanoproduct in medical application. Toxicol Lett 176(1): 1-12.

56. Fox CL, Modak SM (1974) Mechanism of silver sulfadiazine action on burn wound infections. Antimicrob Agents Chemother 5(6): 582-588.

57. Madhumathi K, Sudheesh Kumar PT, Abhilash S, Sreeja V, Tamura H, et al. (2010) Development of novel chitin/nanosilver composite scaffolds for wound dressing applications. J Mater Sci Mater Med 21(2): 807813.

58. Wong KK, Cheung SO, Huang LM, Niu J, Tao C, et al. (2009) Further evidence of the anti-inflammatory effects of silver nanoparticles. ChemMedChem 4(7): 1129-1135.

59. Bhol KC, Schechter PJ (2007) Effects of nanocrystalline silver (NPI 32101) in a rat model of ulcerative colitis. Digestic Diseases and Sciences 52(10): 2732-2742.

60. Pittet D, Tamara D, Wenzel RP (1994) Nosocomial bloodstream infection in critically ill patients: excess length of stay, extra costs, and attributable mortality. JAMA 271(20): 598-601.

61. Mermel LA (2000) Prevention of intravascular catheter-related infections. Annals of Internal Medicine 132(5): 391-402.

62. George SJ, Vuddamalay P, Bosco MJ (1997) Antiseptc-impregnated central venous catheters reduce the incient of bacterial colonization and associated infection in immunocompromised transplant patients. Eur J Anaestheesiol 14(4): 428-431.

63. Tennenberg S, Leiser M, Mccurd B, Boomer G, Howington E, et al. (1997) Aprospective randomized trial of an antibiotic and antiseptic coated central venous catheter in the prevention of catheter related infections. Arch Surg 132(12): 1348-1351.
64. Sheng WH, Ko WJ, Wang IJ, Chang SC, Hsueh PR, et al. (2000) Evaluation of antiseptic impregnated central venous catheters for prevention of catheter related infection in intensive care unit patients. Diagn Microbiol Infect Dis 38(1): 1-5.

65. Khare MD, Bukhari SS, Swan A, Spiers P, McLaren I, et al. (2007) Reduction of catheter related colonization by the use of a silver zeolite impregnated central vascular catheter in adult critical care. J Infect 54(2): 146-150.

66. Ricco JB (2006) Inter Gard silver bifurcated graft: features and results of a multicenter clinical study. J Vasc Surg 44(2): 39-46.

67. Galiano K, Pleifer C, Engelhardt K, Brossner G, Lackner P, et al. (2008) Silver segregation and bacterial growth of intraventricular catheters impregnated with silver nano particles in cerebrospinal fluid drainages. Neurol Res 30: 285-287.

68. Gristina AG (1987) Biomaterial-centered infection; microbial adhesion versus tissue integration. Science 237 (4822): 1588-1595.

69. Alt V, Bechert T, Steinrücke P, Wagener M, Seidel P, et al. (2004) An in vitro assessment of the antibacterial properties and cytotoxicity of nanoparticulate silver bone cement. Biomaterials 25(18): 43834391.

70. Darouiche RO (2004) Treatment of infections associated with surgical mesh. N Ensl J Med 350(14): 1422-1429.

71. Cohen SD (2006) Host selectivity and genetic variation of Discula umbrinella isolates from two oak species: analyses of intergenic spacer region sequences of ribosomal DNA. Microb Ecol 52(3): 463-469.

72. Sun RW, Chen R, Chung NP, Ho CM, Lin CL, et al. (2005) Silver nano particles fabricated in Hepes buffer exhibit cytoprotective activities toward HIV-1 infected cells. Chem Commun (40): 5059-5061.

73. Khalid A (2002) Is Thrombolytic Therapy effective for pulmonary embolism? Am Fam Physician 65(6): 1097-1102.

74. Shrivastava S, Bera T, Singh SK (2009) Characterization of antiplatelet properties of silver nano particles. ACS Nano 3(6): 1357-1364.

\section{Your next submission with Juniper Publishers will reach you the below assets}

- Quality Editorial service

- Swift Peer Review

- Reprints availability

- E-prints Service

- Manuscript Podcast for convenient understanding

- Global attainment for your research

- Manuscript accessibility in different formats

( Pdf, E-pub, Full Text, Audio)

- Unceasing customer service

Track the below URL for one-step submission https://juniperpublishers.com/online-submission.php 